May 1999 • NREL/CP-520-26494

\title{
Passivation of Interfaces in High-Efficiency Photovoltaic Devices
}

S.R. Kurtz, J.M. Olson, D.J. Friedman, J.F. Geisz, and A.E. Kibbler

National Renewable Energy Laboratory

K.A. Bertness

NIST, Boulder, Colorado

Presented at the Materials Research Society's

Spring Meeting

San Francisco, California

April 5-9, 1999

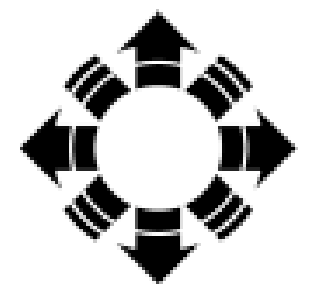

NPEL

National Renewable Energy Laboratory

1617 Cole Boulevard

Golden, Colorado 80401-3393

NREL is a U.S. Department of Energy Laboratory

Operated by Midwest Research Institute $\bullet$ Battelle $\bullet$ Bechtel

Contract No. DE-AC36-98-G010337 


\section{NOTICE}

This report was prepared as an account of work sponsored by an agency of the United States government. Neither the United States government nor any agency thereof, nor any of their employees, makes any warranty, express or implied, or assumes any legal liability or responsibility for the accuracy, completeness, or usefulness of any information, apparatus, product, or process disclosed, or represents that its use would not infringe privately owned rights. Reference herein to any specific commercial product, process, or service by trade name, trademark, manufacturer, or otherwise does not necessarily constitute or imply its endorsement, recommendation, or favoring by the United States government or any agency thereof. The views and opinions of authors expressed herein do not necessarily state or reflect those of the United States government or any agency thereof.

Available to DOE and DOE contractors from:

Office of Scientific and Technical Information (OSTI)

P.O. Box 62

Oak Ridge, TN 37831

Prices available by calling 423-576-8401

Available to the public from:

National Technical Information Service (NTIS)

U.S. Department of Commerce

5285 Port Royal Road

Springfield, VA 22161

$703-605-6000$ or $800-553-6847$

or

DOE Information Bridge

http://www.doe.gov/bridge/home.html

Printed on paper containing at least $50 \%$ wastepaper, including $20 \%$ postconsumer waste 


\title{
PASSIVATION OF INTERFACES IN HIGH-EFFICIENCY PHOTOVOLTAIC DEVICES
}

\author{
S. R. KURTZ, J. M. OLSON, D. J. FRIEDMAN, J. F. GEISZ, K. A. BERTNESS*, \\ and A. E. KIBBLER \\ National Renewable Energy Laboratory (NREL) \\ 1617 Cole Blvd., Golden, CO 80401,Sarah_Kurtz@nrel.gov \\ *NIST, 325 Broadway, Boulder, CO, 80303
}

\begin{abstract}
Solar cells made from III-V materials have achieved efficiencies greater than $30 \%$. Effectively ideal passivation plays an important role in achieving these high efficiencies. Standard modeling techniques are applied to $\mathrm{Ga}_{0.5} \mathrm{In}_{0.5} \mathrm{P}$ solar cells to show the effects of passivation. Accurate knowledge of the absorption coefficient is essential (see appendix). Although ultralow $(<2 \mathrm{~cm} / \mathrm{s})$ interface recombination velocities have been reported, in practice, it is difficult to achieve such low recombination velocities in solar cells because the doping levels are high and because of accidental incorporation of impurities and dopant diffusion. Examples are given of how dopant diffusion can both help and hinder interface passivation, and of how incorporation of oxygen or hydrogen can cause problems.
\end{abstract}

\section{INTRODUCTION}

III-V solar cells can achieve very high efficiencies (80-90\% of theoretical efficiency) because the material quality and interface passivation are almost ideal. The $\mathrm{Ga}_{0.5} \mathrm{In}_{0.5} \mathrm{P} / \mathrm{GaAs}$ twojunction solar cell, invented and developed at NREL, has achieved high efficiencies of around $30 \%$ [1-3] and is in large-scale production [4,5]. We have shown that very low (as low as 1.5 $\mathrm{cm} / \mathrm{s}$ [6]) interface recombination velocities (IRV) can be achieved for the $\mathrm{Ga}_{0.5} \mathrm{In}_{0.5} \mathrm{P} / \mathrm{GaAs}$ interface. However, in actual device structures, much higher IRVs are often observed. A detailed understanding of the structures and growth of solar cells is necessary to obtain effectively ideal interfaces (i.e., ones with IRVs less than $10,000 \mathrm{~cm} / \mathrm{s}$.) In this paper, we calculate the effects of passivation of the front and back of $\mathrm{Ga}_{0.5} \mathrm{In}_{0.5} \mathrm{P}$ (hereafter, GaInP) solar cells on both the photocurrent and photovoltage, and give examples of how and why ideal passivation is not always achieved.

\section{THEORETICAL APPROACH}

We present here a brief description of the importance of interface passivation to photovoltaic device operation, using the GaInP cell as an example. Thorough treatments of photovoltaic devices can be found elsewhere [7,8]. A schematic for a solar cell is shown in Fig. 1. For convenience, we discuss an n-on-p structure, but this discussion also applies to a p-on-n structure with appropriate redefinition of terms. High-efficiency III-V solar cells typically use a thin $(\sim 0.1$ $\mu \mathrm{m}) \mathrm{n}$ layer, commonly referred to as the emitter of the device (Fig. 1). The solar spectrum, striking the front of the cell, includes ultraviolet, visible, and infrared light. The absorption coefficient for short-wavelength light (referred to hereafter as "blue" light) is quite large, and most of the blue light is absorbed very close to the front of the cell-generating photocarriers in 
the emitter layer. Light with energy close to, but above the band edge (referred to hereafter as "red" light), is weakly absorbed (generates photocarriers) throughout the cell. Sub-band-gap light is not absorbed and passes through the cell. The photocarriers generated by the super-bandgap light diffuse inside the cell until they are either collected at the $\mathrm{p}-\mathrm{n}$ junction or recombine with a majority carrier, either by bulk or interface recombination. The efficiency of the solar cell is increased when all the photocarriers are collected at the junction instead of recombining elsewhere. Thus, effective passivation of the front and back of the cell improves the efficiency of the cell.

An ideally passivated interface "reflects" minority carriers, but passes majority carriers. Examples of two such interfaces are included in Fig. 1. The passivating layer at the front of the cell is often referred to as the "window" layer because it must be transparent if the solar cell is to have a high efficiency. The back of the cell is passivated by a structure referred to as a "back-

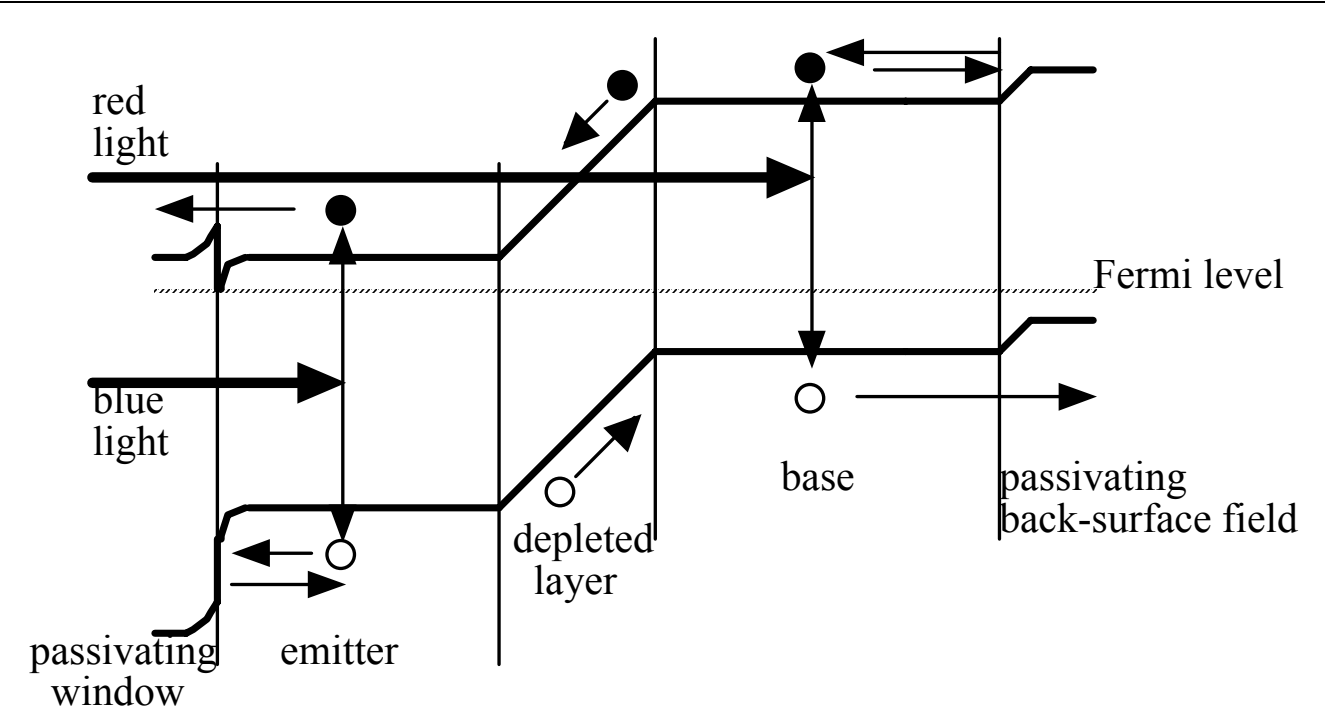

Fig. 1. Schematic of an n-on-p solar cell. Blue light is strongly absorbed close to the front of the cell, generating photocarriers in the emitter. Red light is absorbed throughout the cell. The photo-generated minority carriers diffuse within the emitter and base, may be "reflected" by the passivating layers, and are collected at the junction by the field in the depleted layer. The resulting majority carriers then pass through the passivating layers and are used in an external circuit.

surface field." This layer does not need to have a higher band gap as long as it provides an adequate barrier to minority carriers. This can sometimes be provided primarily by increased doping in the passivating layer (for n-type GaAs and for GaInP), as shown in Fig. 1, but a higher band gap material may work more reliably, especially when doping causes a reduction in the band gap, as in the case of p-type GaAs.

The current-voltage (IV) curve for a solar cell (Fig. 2) in the dark is given by the standard diode equation. If superposition holds (and the photocurrent is independent of the voltage), the light IV curve has the same shape as the dark IV curve, but is shifted downward by the shortcircuit current $\left(\mathrm{J}_{\mathrm{sc}}\right)$. The open-circuit voltage $\left(\mathrm{V}_{\mathrm{oc}}\right)$ is the voltage at which the magnitude of the 
dark current equals the $\mathrm{J}_{\mathrm{sc}}$. The maximum power output of the solar cell is given by the product of the $\mathrm{J}_{\mathrm{sc}}$, the $\mathrm{V}_{\mathrm{oc}}$, and the fill factor (a measure of the "squareness" of the IV curve). Passivation of the front and back of the solar cell increases both the $\mathrm{J}_{\mathrm{sc}}$ and the $\mathrm{V}_{\mathrm{oc}}$. We first describe the effect of the passivation on the $\mathrm{J}_{\mathrm{sc}}$, and then on the $\mathrm{V}_{\mathrm{oc}}$.

If certain assumptions are made, including a device structure with uniform layers similar to that shown in Fig. 1, low injection, and ideal semiconductor material, the transport equations can be solved in closed form $[7,8]$. The quantum efficiency $(\mathrm{QE})$, defined as the probability of

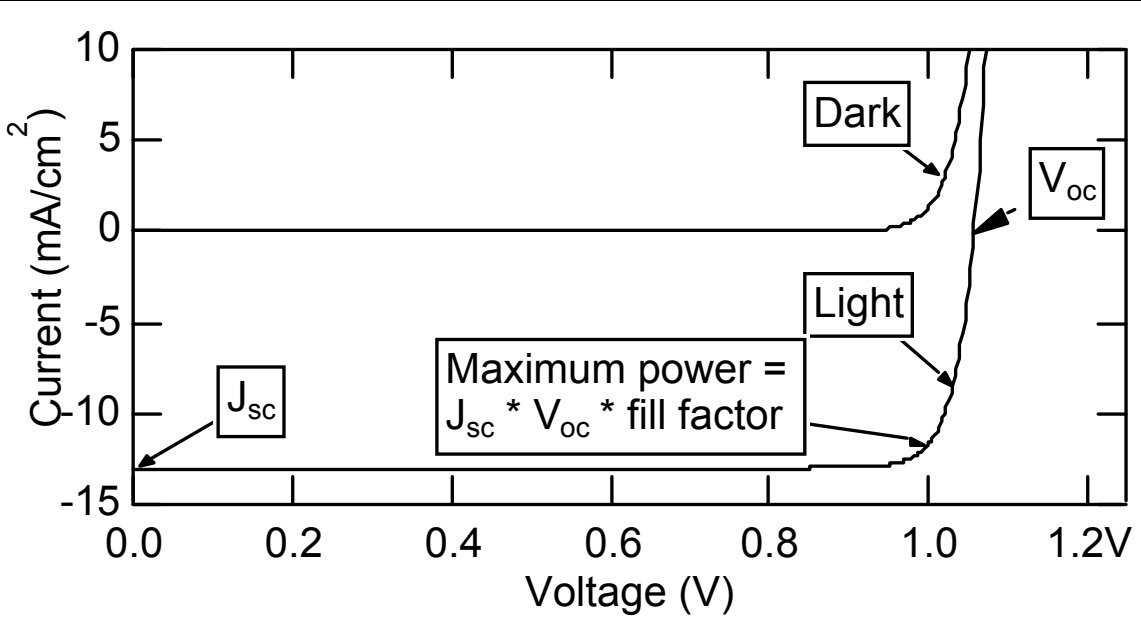

Fig. 2. Dark and light IV curves for a solar cell. The short-circuit current, open-circuit voltage, and maximum power point are labeled.

collecting a photocarrier for each photon, is given for the emitter region by

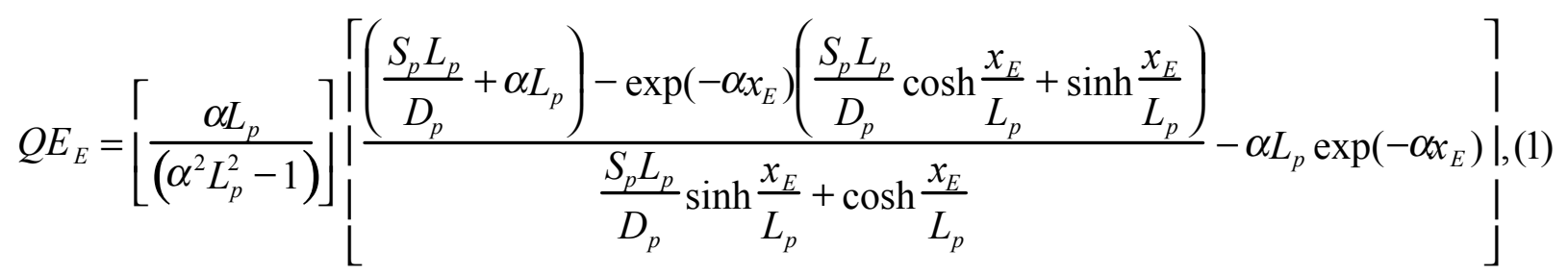

where the variables are defined in Table 1 .

Similarly, the probability of collecting a photocarrier from the base is given by

$\left.Q E_{B}=\frac{\alpha L_{n}}{\alpha^{2} L_{n}^{2}-1} \exp \left[-\alpha\left(x_{E}+W_{D}\right)\right] \mid \alpha L_{n} \frac{\frac{S_{n} L_{n}}{D_{n}}\left(\cosh \frac{x_{B}}{L_{n}}-\exp \left(-\alpha x_{B}\right)\right)+\sinh \frac{x_{B}}{L_{n}}+\alpha L_{n} \exp \left(-\alpha x_{B}\right)}{\frac{S_{n} L_{n}}{D_{n}} \sinh \frac{x_{B}}{L_{n}}+\cosh \frac{x_{B}}{L_{n}}}\right\rceil .(2)$ 
Table 1. Definitions of symbols and values (for GaInP) used for the fit in Fig. 3. The values specified in parentheses were used for calculations presented in other figures. Correction for absorption in a $0.025-\mu \mathrm{m}$-thick $\mathrm{Al}_{0.5} \mathrm{In}_{0.5} \mathrm{P}$ window layer was also included.

\begin{tabular}{|c|l|l|}
\hline Symbol & \multicolumn{1}{|c|}{ Significance } & \multicolumn{1}{c|}{ Value } \\
\hline$\alpha$ & absorption coefficient & see appendix \\
\hline$L_{p}$ & hole diffusion length in n-type emitter material & $0.5 \mu \mathrm{m}$ \\
\hline$L_{n}$ & electron diffusion length in p-type base material & $3 \mu \mathrm{m}$ \\
\hline$S_{p}$ & surface recombination velocity at window & $10^{4}\left(10^{4}-10^{7}\right) \mathrm{cm} / \mathrm{s}$ \\
\hline$S_{n}$ & $\begin{array}{l}\text { surface recombination velocity at back-surface } \\
\text { field }\end{array}$ & $1.7 \times 10^{6}\left(10^{4}-10^{7}\right) \mathrm{cm} / \mathrm{s}$ \\
\hline$D_{p}$ & diffusion coefficient of holes in n-type material & $5 \mathrm{~cm}^{2} / \mathrm{s}$ \\
\hline$D_{n}$ & $\begin{array}{l}\text { diffusion coefficient of electrons in p-type } \\
\text { material }\end{array}$ & $100 \mathrm{~cm}^{2} / \mathrm{s}$ \\
\hline$x_{E}$ & emitter thickness (flat-band) & $0.1 \mu \mathrm{m}$ \\
\hline$W_{D}$ & depletion width & $0.1 \mu \mathrm{m}$ \\
\hline$x_{B}$ & base thickness (flat-band) & $0.45(3) \mu \mathrm{m}$ \\
\hline
\end{tabular}

In the depleted layer, the electric field aids the collection of photocarriers, resulting in collection of every photocarrier generated there, as calculated by:

$Q E_{D}=\exp \left(-\alpha x_{E}\right)\left[1-\exp \left(-\alpha W_{d}\right)\right]$

The total internal QE is obtained by summing the contributions of the emitter, base, and depleted layers (eqs. 1-3). The $\mathrm{QE}$ is a function of wavelength, $\lambda$, because of the $\lambda$-dependence of the absorption coefficient, $\alpha$. In practice, the external QE and the reflectivity are measured, and the internal $\mathrm{QE}$ calculated from the external $\mathrm{QE}(\lambda)$ divided by $[1-\mathrm{R}(\lambda)]$, where $\mathrm{R}(\lambda)$ is the reflectivity as a function of $\lambda$. The $\mathrm{J}_{\mathrm{sc}}$ is obtained from the integral of the product of the QE with the spectrum of interest. Fig. 3 shows a fit to data, including the contributions from the three regions. For all of the curves presented in this paper, the $\mathrm{QE}$ was also reduced to account for absorption in a $0.025-\mu \mathrm{m}$-thick $\mathrm{Al}_{0.5} \mathrm{In}_{0.5} \mathrm{P}$ window layer. In practice, it is very difficult to differentiate low $L_{n}$ from high $S_{n}$. An equally good fit was obtained by using a $S_{n}<10^{4} \mathrm{~cm} / \mathrm{s}$ and $L_{n}$ of about $0.5 \mu \mathrm{m}$. We emphasize that the quality of the fit is very dependent on our knowledge of $\alpha(\lambda)$ (see appendix).

Figs. 4 and 5 show the total internal QEs calculated from eqs. 1-3 using the parameters in Table 1, and varying the values for $S_{p}$ and $S_{n}$. For large absorption coefficients, a high $S_{p}$ causes the blue response to decrease dramatically (Fig. 4). However, a high $S_{p}$ also causes a reduction in the red response as well. In contrast, high $S_{n}$ causes a reduction only in the red response, with almost no measurable effect in the blue response for a thick cell (Fig. 5). 


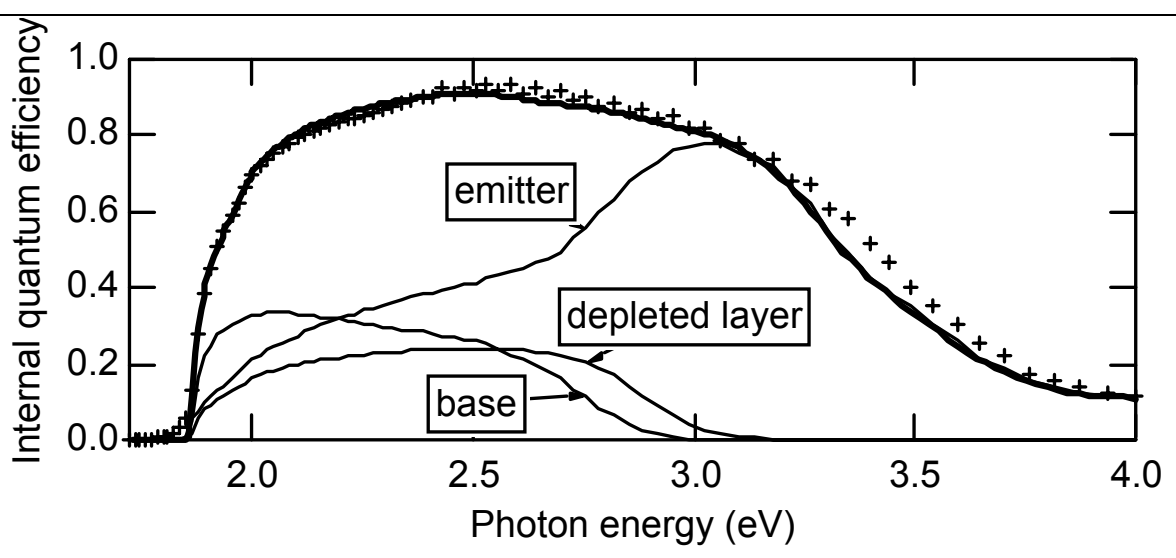

Fig. 3. Measured (+) and modeled (lines) internal quantum efficiency for a GaInP cell. The contributions of the three regions are shown in addition to their sum (heavy line). The calculated curves used Eqs. 1-3 with the values specified in Table 1, including $S_{n}=1.7 \times 10^{6} \mathrm{~cm} / \mathrm{s}$.

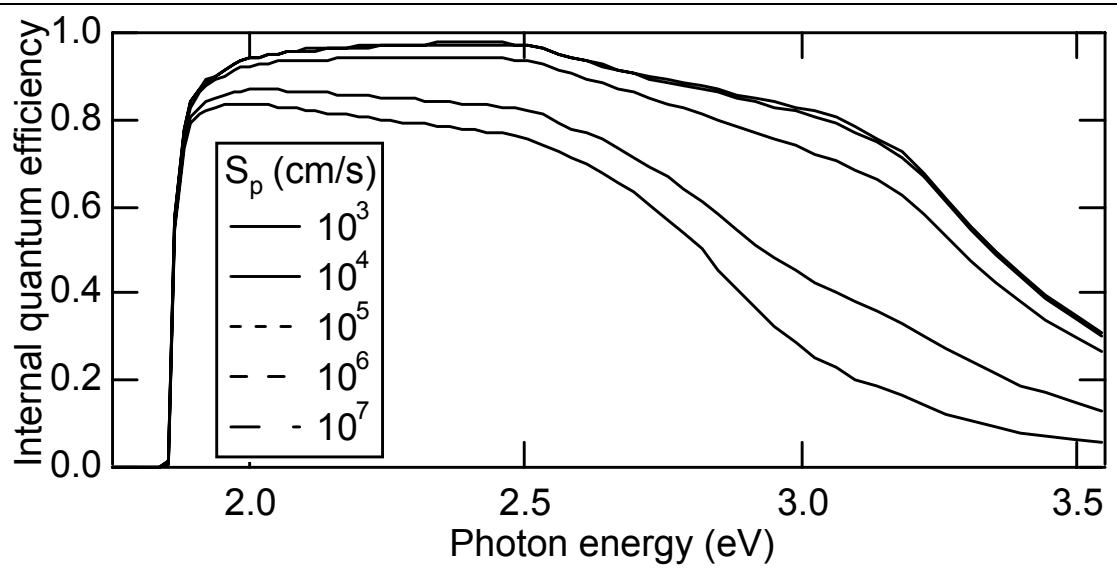

Fig. 4. Internal QE calculated using $x_{B}=3 \mu \mathrm{m}, S_{n}=1000 \mathrm{~cm} / \mathrm{s}$, and a variable value of $S_{p}$.

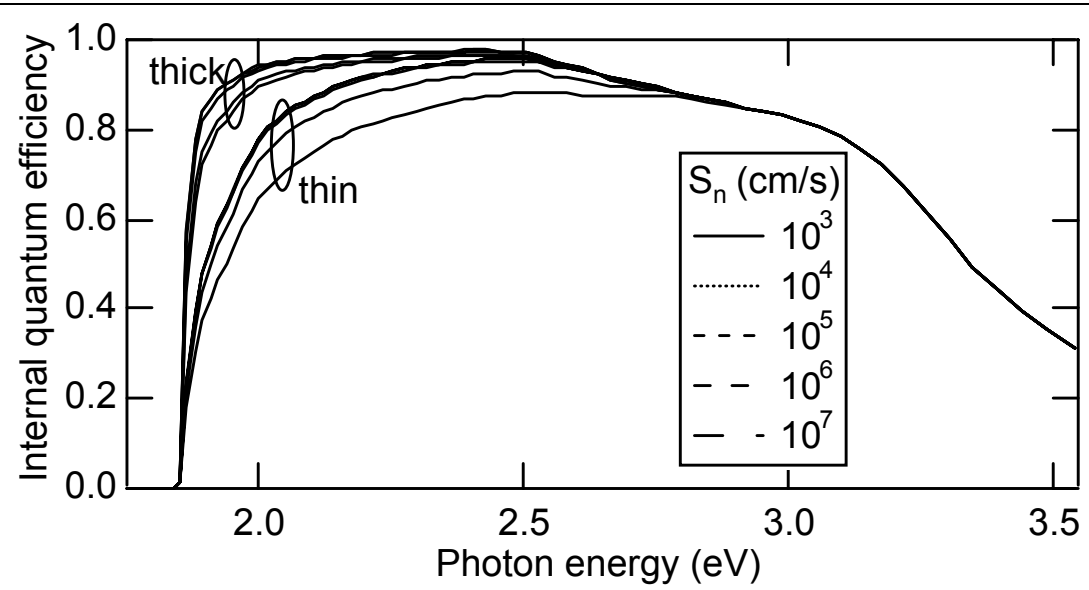

Fig. 5. Internal QE calculated using a variable value of $S_{n}$. The lower set of curves used $x_{B}=0.45 \mu \mathrm{m}$; for the upper set, $x_{B}=3 \mu \mathrm{m}$. 
If the cell is thinned so that more light penetrates near the back surface, then an increase in $S_{n}$ causes a decrease of both the red and the blue response, with the red response decreasing even more dramatically. The most significant result here is that the $\mathrm{QE}$ is increased when $S_{n}$ or $S_{p}$ is reduced from $10^{7}$ to about $10^{4} \mathrm{~cm} / \mathrm{s}$, but further reduction of $S_{n}$ or $S_{p}$ has a negligible effect on the QE.

Similar calculations for p-on-n cells show that the effect of passivation of the back of the cell is less than for the n-on-p cell. In practice, a p-on-n cell usually uses a thicker emitter and thinner base. The differences observed between the n-on-p and p-on-n cell are a result of the poor minority hole transport properties compared with those of electrons. Poor hole collection in a $0.1-\mu \mathrm{m}$-thick, $n$-type emitter is not a serious problem in the $n$-on-p cell, but is much more of a problem in a 3- $\mu \mathrm{m}$-thick, n-type base of a p-on-n cell. However, in practice, because most GaInP cells are grown thin to help match the currents of the GaInP and GaAs cells [9], both cells require passivation of both the front and the back of the cells. Thick GaAs p-on-n cells benefit negligibly from back-surface passivation because the base thickness $\geq L_{p}$.

Passivation of the solar cell also decreases the dark current of the solar cell, and, therefore, increases the $\mathrm{V}_{\mathrm{oc}}$. Assuming ideal material, the transport equations can be solved to give the dark current associated with the base and emitter regions (first two terms in eq. 4) [7,8]. An estimation of the dark current in the depleted layer is included as the third term [8] and is discussed below.

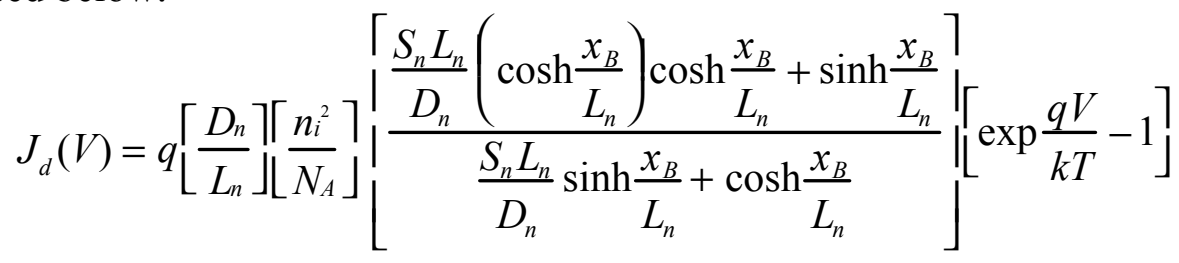

$$
\begin{aligned}
& \left.\left.\left.+q\left[\frac{D_{p}}{L_{p}}\right\rceil \frac{n_{i}^{2}}{N_{D}}\right\rfloor\left|\frac{\left.\frac{S_{p} L_{p}}{D_{p}}\left(\cosh \frac{x_{E}}{L_{p}}\right) \cosh \frac{x_{E}}{L_{p}}+\sinh \frac{x_{E}}{L_{p}}\right\rceil}{\frac{S_{p} L_{p}}{D_{p}} \sinh \frac{x_{E}}{L_{p}}+\cosh \frac{x_{E}}{L_{p}}}\right|_{\mid}\right] \exp \frac{q V}{k T}-1\right\rfloor^{+}\left\lfloor\frac{n_{i} W_{d} k T}{2\left(V_{d}-V\right) \tau}\right]\left[\exp \frac{q V}{2 k T}-1\right]
\end{aligned}
$$

where $\mathrm{n}_{\mathrm{i}}$ is the intrinsic carrier concentration, $N_{A}$ and $N_{D}$ are the concentrations of acceptors and donors, $V_{d}$ is the built-in voltage, and $\tau$ is the nonradiative carrier lifetime, given by $1 / \mathrm{N}_{\mathrm{T}} \sigma v_{\text {th }}$, the reciprocal of the product of the trap density, the capture cross section, and the thermal carrier velocity [8].

The base and emitter terms are the diode injection current and are affected both by bulk recombination and by interface recombination. The impact of the two types of recombination on the relative $V_{o c}$ can be expressed as a function of two dimensionless variables [9]. The bulk recombination is described by the ratio of the layer thickness to the diffusion length, $\mathrm{x} / \mathrm{L}$, and the ratio of the interface recombination to bulk recombination by SL/D (Fig. 6). The same results are applicable for both n- and p-type material, so the subscripts have been removed in Fig. 6. For thick layers or short diffusion lengths (layer thickness $>$ diffusion length), the bulk recombination 
dominates and the $\mathrm{V}_{\mathrm{oc}}$ is independent of SL/D. For thin layers, the interface recombination strongly affects the $\mathrm{V}_{\mathrm{oc}}$. Just as the $\mathrm{QE}$ is not affected by passivation of the back of a GaAs p-on$\mathrm{n}$ cell (for which $x_{B} \geq L_{p}$ ), the $\mathrm{V}_{\mathrm{oc}}$ is also not affected.

The third term in eq. 4 estimates recombination at defects in the depleted layer. This Shockley-Read-Hall (SRH) recombination is strongest in the part of the depleted layer for which the intrinsic level is approximately midway between the electron and hole quasi-Fermi levels. The equations describing the SRH recombination cannot be solved in closed form. In practice, the SRH recombination is difficult to quantify because the trap state density, energy, and capture cross section are usually not well known. Also, errors may be introduced because of approximating the third term in eq. 4 [10].

The terms in eq. 4 can be differentiated by their voltage dependencies. The first two terms show an exponential dependence on $\mathrm{qV} / \mathrm{nkT}$ with $\mathrm{n}$ (diode quality factor) is equal to unity. In contrast, the third term shows an exponential dependence on $\mathrm{V}$ with $\mathrm{n}=2$ and an additional $\mathrm{V}$ dependence in the preexponential. Therefore, the depleted layer dark current is sometimes referred to as " $n=2$ " current. In practice, the voltage at the maximum-power-point on the IV curves of small high-efficiency cells may be dominated by an $n=2$ dark current that comes from

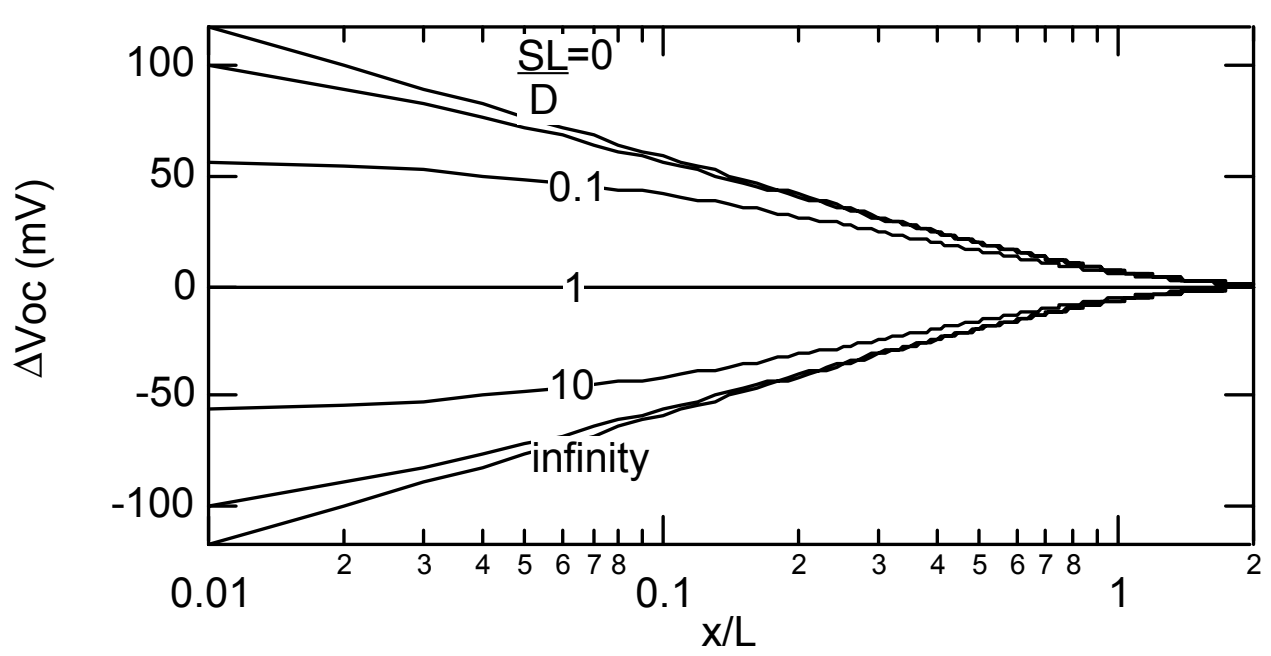

Fig. 6. Change in $\mathrm{V}_{\mathrm{oc}}$ with the dimensionless thickness ( $\mathrm{x} / \mathrm{L}$ ) as the ratio of the interface/bulk recombination (SL/D) is varied from 0 to infinity. The values apply to either p-type or n-type material.

recombination at the perimeter of the cells. This perimeter recombination can be reduced by passivation of the III-V exposed junction surfaces [11]. Despite the $\mathrm{qV} / 2 \mathrm{kT}$ term in the exponential, SRH recombination in the depleted region may show $\mathrm{n}<2$ because of the $\mathrm{V}$ dependence of the preexponential. In extreme cases, $n$ may approach unity even when the dark current is dominated by SRH recombination [8].

When a solar cell is inefficient, the cause may be poor passivation, but it may also be something else. When the $\mathrm{V}_{\mathrm{oc}}$ is low, a diode quality factor of 2 implies that the problem is in 
the depleted layer. An example of an extreme case of this is shown in Fig. 7. Both the $n=2$ nature of the dark current and the micrograph imply that recombination at defects in the depleted layer is the cause of the high dark current. When the $\mathrm{V}_{\mathrm{oc}}$ is poor and the diode quality factor is unity, the cause may be either bulk or interface recombination. These, theoretically, can be differentiated by varying the thickness of the layer. If the $\mathrm{V}_{\mathrm{oc}}$ improves as the cell is thinned, then the problem is likely to be bulk recombination. If the $\mathrm{V}_{\mathrm{oc}}$ is reduced by thinning, then poor interface passivation is suspected. If the $\mathrm{V}_{\mathrm{oc}}$ is unchanged, then, either $\mathrm{x}>\mathrm{L}$ or the bulk and interface recombinations are of equal importance.

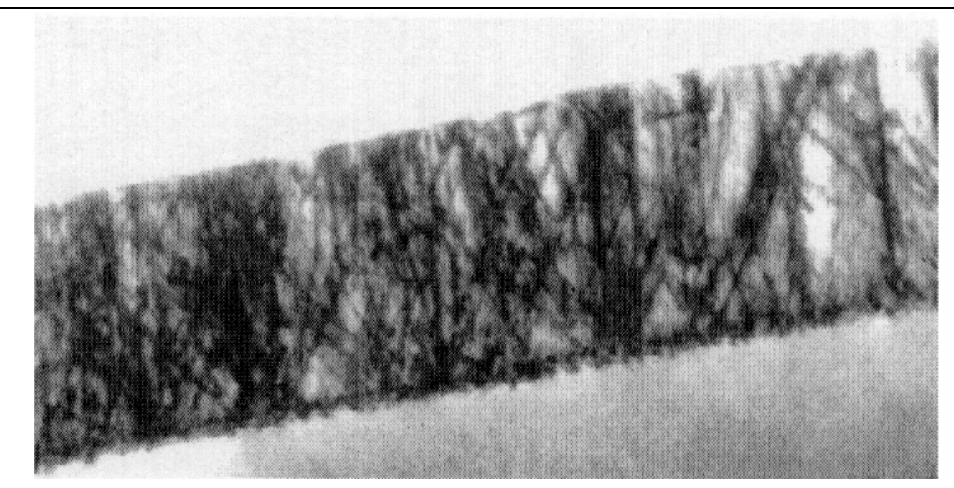

Fig. 7. Transmission electron micrograph of GaInP cell showing very high $\mathrm{n}=2$ dark current.

\section{EXPERIMENTAL DATA}

Table II summarizes a few interface recombination velocities measured on double heterostructures. All (except for one) of these values are low compared with the values used in calculating the data in Figs. 3-5, implying that it should be possible to grow solar cells with essentially no losses from poor surface passivation. However, the data in Table II demonstrate that the IRV increases with both the doping of the active layer and with aluminum content of the passivating layer. Substitution of aluminum for gallium in most III-V materials increases the band gap without significantly changing the lattice constant. Thus, theoretically, aluminumcontaining III-V materials make ideal passivating layers. However, practically, the use of aluminum is much more difficult because of the gettering of oxygen that comes with increased aluminum content, and because of the tendency of aluminum-containing alloys to form DX centers. The one IRV in Table II that is greater than $10^{4} \mathrm{~cm} / \mathrm{s}$ is the passivation of p-type GaInP with p-type AlGaInP. In the GaInP/GaAs solar cell the p-type GaInP is the most challenging layer to passivate because p-type AlInP and AlGaInP are so sensitive to low levels of oxygen.

One very interesting result shown in Table II is the use of disordered GaInP to passivate GaInP. The band gap of GaInP (at a fixed composition) varies with growth conditions because of ordering of the Ga and In atoms on the group III sublattice [12,13]. Thus, a high-band-gap (disordered) GaInP layer can be used to passivate a low-band-gap (partially ordered) GaInP layer. Higher doping also tends to create a passivating layer. (This works well for n-type GaAs, but is less effective for p-type GaAs because of heavy doping effects [14]). One of the examples cited in Table II and several of the results reported below use a high-band-gap, high-zinc-doped GaInP 
layer to passivate a second GaInP layer with lower band gap and lower zinc doping. The movement of zinc in a GaInP layer has been shown to disorder an ordered GaInP layer [15]. Thus, a passivating GaInP layer can be formed by diffusing zinc into it. An example of this will be discussed below.

Table II. Interface recombination velocities reported in the literature for GaAs or GaInP layers sandwiched between two barrier layers.

\begin{tabular}{|c|c|c|c|}
\hline GaAs doping $\left(\mathrm{cm}^{-3}\right)$ & Barrier & $\mathrm{S}(\mathrm{cm} / \mathrm{s})$ & Reference \\
\hline $\mathrm{n}<10^{16}$ & $\mathrm{Al}_{0.3} \mathrm{Ga}_{0.7} \mathrm{As}$ & 18 & {$[16]$} \\
\hline $\mathrm{n}<10^{15}$ & $\mathrm{Ga}_{0.5} \operatorname{In}_{0.5} \mathrm{P}$ & $<1.5$ & {$[6]$} \\
\hline $\mathrm{n}=1-3 \times 10^{18}$ & $\mathrm{Ga}_{0.5} \operatorname{In}_{0.5} \mathrm{P}$ & 1300 & [17] \\
\hline $\mathrm{n}=1.3 \times 10^{17}$ & $\mathrm{Al}_{0.3} \mathrm{Ga}_{0.7} \mathrm{As}$ & $<12$ & {$[18]$} \\
\hline $\mathrm{p}=5 \times 10^{15}$ & $\mathrm{Al}_{0.5} \mathrm{Ga}_{0.5} \mathrm{As}$ & 300 & [19] \\
\hline$p=3 \times 10^{16}$ & $\mathrm{Al}_{0.5} \mathrm{Ga}_{0.5} \mathrm{As}$ & 350 & [19] \\
\hline $\mathrm{p}=1.7 \times 10^{17}$ & $\mathrm{Al}_{0.5} \mathrm{Ga}_{0.5} \mathrm{As}$ & 500 & [19] \\
\hline \multicolumn{4}{|l|}{$\mathrm{Ga}_{0.5} \mathrm{In}_{0.5} \mathrm{P}$ doping $\left(\mathrm{cm}^{-3}\right)$} \\
\hline $\mathrm{p}=9 \times 10^{16}$ & $\mathrm{Al}_{0.25} \mathrm{Ga}_{0.25} \operatorname{In}_{0.5} \mathrm{P}$ & 140,000 & {$[17]$} \\
\hline $\mathrm{n}<10^{15}$ & disordered $\mathrm{Ga}_{0.5} \operatorname{In}_{0.5} \mathrm{P}$ & $<2$ & \multirow[t]{5}{*}{ [20] } \\
\hline $\mathrm{n}<10^{15}$ & $\mathrm{Al}_{0.25} \mathrm{Ga}_{0.25} \operatorname{In}_{0.5} \mathrm{P}$ & 7 & \\
\hline $\mathrm{n}<10^{15}$ & $\mathrm{Al}_{0.5} \operatorname{In}_{0.5} \mathrm{P}$ & 85 & \\
\hline $\mathrm{n}<10^{15}$ & $\mathrm{Al}_{0.5} \mathrm{Ga}_{0.5} \mathrm{As}$ & 180 & \\
\hline $\mathrm{n}<10^{15}$ & $\mathrm{Al}_{0.85} \mathrm{Ga}_{0.15} \mathrm{As}$ & $>5000$ & \\
\hline
\end{tabular}

Although aluminum-containing alloys are attractive candidates for passivating layers, they often cause incorporation of oxygen, leading to enhanced recombination at interfaces. Such an effect of poor passivation because of oxygen contamination in an $\mathrm{Al}_{0.5} \mathrm{In}_{0.5} \mathrm{P}$ window layer is shown in Fig. 8 [21]. Oxygen incorporation can also lead to majority-carrier transport problems.

One challenge of achieving the low IRVs noted in Table II in solar cells is that growth of devices with p-n junctions sometimes causes dopant diffusion. The dopant diffusion may either help or hinder the passivating layers. Specifically, growth of n-type layers on top of Zn-doped layers has been shown to cause diffusion of the $\mathrm{Zn}$. Deppe put forth an explanation for this effect that explains a significant fraction of the data [22]. He hypothesized that Fermi-level pinning at the growth surface controls the concentration of point defects. Although an equilibrium concentration of $\mathrm{Ga}$ interstitials is obtained at the growing surface, when that layer is covered by subsequent growth layers and the Fermi level shifts back to its normal value, there is then an excess concentration of Ga interstitials. These move into the underlying zinc-doped layers where they "kick out" zinc atoms, freeing them to diffuse through the material [22]. Although it is difficult to prove or disprove this model, the dopant diffusion can easily be observed (Fig. 9) [23]. The measured QEs of these samples are shown in Fig. 10. The sample with the degraded back-surface field also shows degraded red response (around $2 \mathrm{eV}$ ), as would be predicted (compare to Fig. 5). The change of blue response is less surprising because we calculate that changing the emitter will change the blue response. As pointed out below, diffusion of $\mathrm{Zn}$ at the back of the GaInP cell does not necessarily result in a degraded back-surface field. The situation 
can be more complex than only an increase in $S_{n}$, since the diffusion of $\mathrm{Zn}$ causes the GaInP to become disordered and higher in band gap, which also reduces the red response.

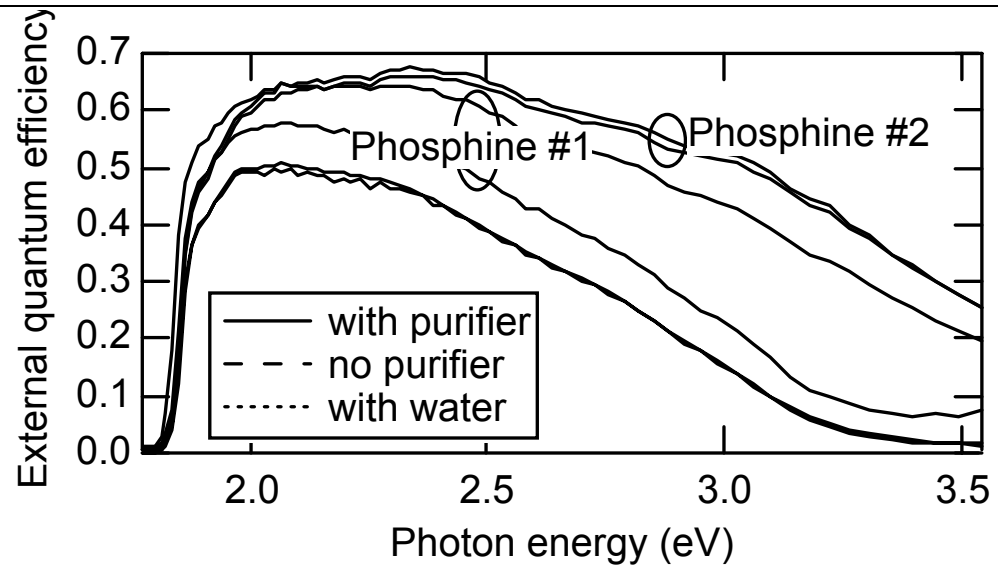

Fig. 8. QE of GaInP cells with and without a phosphine purifier for two different phosphine sources and when water was added (two different runs) intentionally by passing $0.1 \mathrm{sccm}$ of hydrogen through a bubbler containing water at $3^{\circ} \mathrm{C}$. The with-purifier performances differ for the two phosphine sources because the device structures were different. The top four curves were measured on two-junction (GaInP/GaAs) devices.
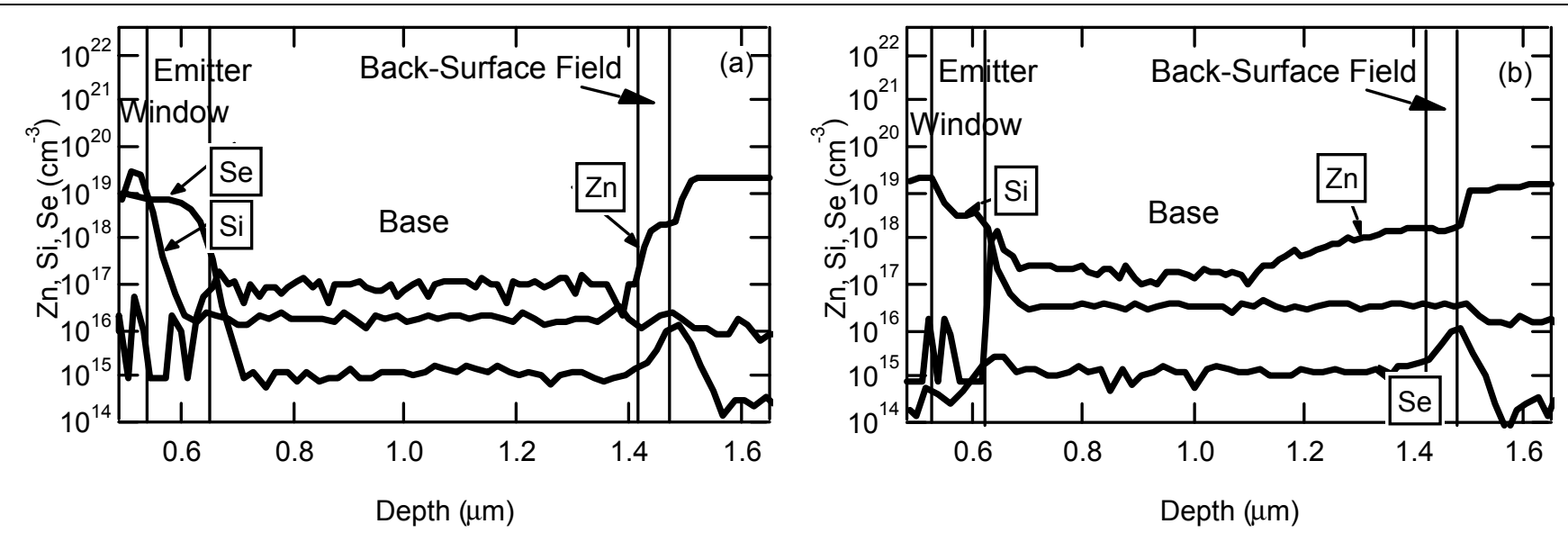

Fig. 9. Secondary Ion Mass Spectra of $\mathrm{Zn}, \mathrm{Si}$, and $\mathrm{Se}$ for a GaInP cell. The two cells were grown identically except for the $\mathrm{Se}(\mathrm{a})$ and $\mathrm{Si}$ (b) doping of the emitter and cap layers. Both used Si doping in the window. In (b) the $\mathrm{Zn}$ is observed to diffuse out of the back-surface field.

The data in Figs. 8 and 9 show how growth-induced dopant diffusion can harm intentionally added passivating layers, but the dopant diffusion can also create an unintentional passivating layer. For example, Table III compares the $\mathrm{V}_{\mathrm{oc}} \mathrm{s}$ of three GaInP cells grown identically except for the choice of the back-surface field. In this case, dopant diffusion from the Zn-doped GaAs buffer layer caused the back-most part of the GaInP base to become disordered and highly doped: almost an ideal back-surface field.

This $\mathrm{Zn}$ diffusion is often avoided in transistor structures by using carbon as the p-type dopant instead of $\mathrm{Zn}$. However, $\mathrm{C}$ doping of GaInP does not work well, and the solution for 
GaInP cells is more difficult, especially when $\mathrm{Si}$ is the n-type dopant. However, $\mathrm{Zn}$ diffusion can be avoided, even in Si-doped GaInP cells, if the back of the n-on-p GaInP cell is passivated by using a clean, p-type AlInP layer. The p-type AlInP passivation leads to lower $\mathrm{V}_{\mathrm{oc}} \mathrm{s}$ and increases the series resistance if the AlInP layer is not clean [24].

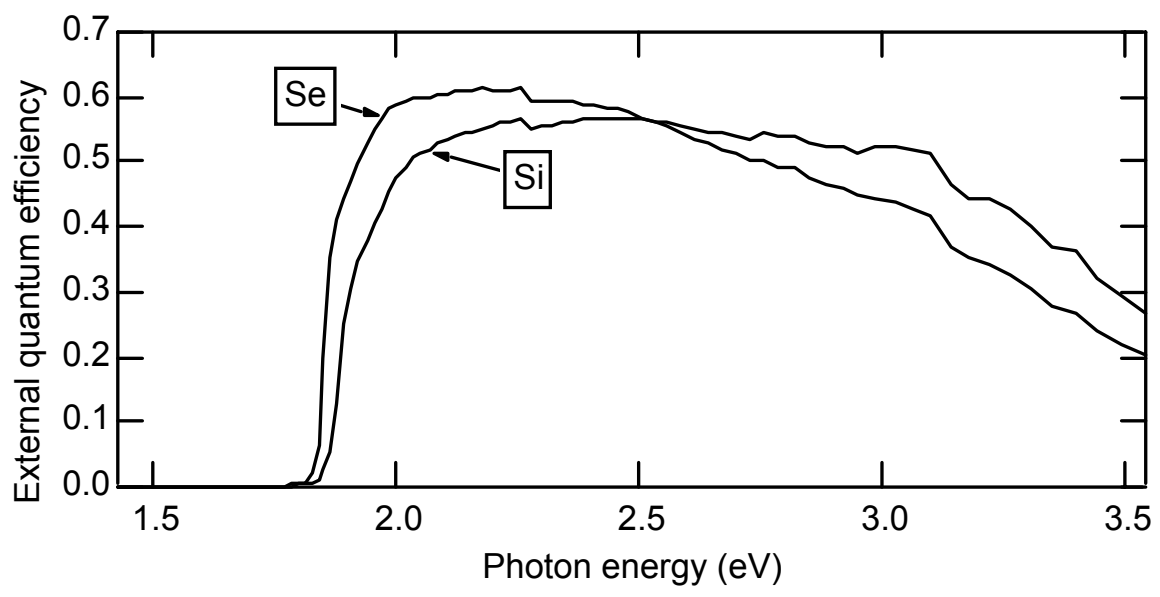

Fig. 10. External quantum efficiency of cells grown like those documented in Fig. 9, showing the poor back-surface passivation (lower $\mathrm{QE}$ at $2 \mathrm{eV}$ ) when zinc diffusion occurs. The change in blue response with change of emitter dopant is not surprising.

Table III. Open-circuit voltages of n-on-p GaInP cells, showing how unintentional $\mathrm{Zn}$ diffusion from a GaAs buffer can increase the $\mathrm{V}_{\mathrm{Oc}}$ almost as much as the intentional back-surface field design.

\begin{tabular}{|l|c|}
\hline Back-surface-field design & $\mathbf{V}_{\mathbf{o c}}(\mathbf{V})$ \\
\hline Intentional high- $\mathrm{E}_{\mathrm{g}}$ GaInP & 1.348 \\
\hline Zn:GaAs buffer (no intentional back-surface field) & 1.335 \\
\hline C:GaAs buffer (no intentional back-surface field) & 1.275 \\
\hline
\end{tabular}

An ideal passivating interface (window or back-surface-field shown in Fig. 1) must not only reflect minority carriers, but must pass majority carriers. For example, problems are encountered if a conduction-band spike impedes electron transport past an interface between two n-type layers. This can happen for a number of reasons. We report next a problem with hole transport across a p-type AlInP/GaInP interface for a p-on-n GaInP solar cell.

Hydrogen passivation of zinc (and other) acceptors results in a reduced hole concentration. After chemical vapor deposition of GaAs and related materials, the sample is traditionally cooled in an arsine (or phosphine)-containing gas ambient to prevent loss of arsenic (or phosphorus) from the surface. The arsine is known to decompose on the surface, creating atomic hydrogen that can diffuse into the semiconductor material. In p-type material, atomic hydrogen is positively charged, and the resulting proton moves very rapidly. In n-type material, the proton picks up an electron and is much less mobile. Thus, atomic hydrogen diffusing into a p-on-n structure is concentrated in the p-type layer, dramatically reducing the hole concentration in the p-type layer. The hole concentration may be reduced to a value where the majority hole transport 
is impeded. This is especially a problem with p-type AlInP for which oxygen impurities compensate zinc acceptors[21]. In Fig. 11 we compare the IV curves of two GaInP p-on-n cells that were grown under identical conditions including a final GaAs cap that is used as a contacting layer, but removed from the active areas of the cells. Although the growth conditions were identical, one cell was cooled under arsine while the other was cooled with no arsine (both used molecular hydrogen as the primary gas ambient, but the molecular hydrogen does not decompose into atomic hydrogen under these conditions). Fig. 11 shows that the sample cooled in arsine shows a non-ohmic series resistance associated with the GaInP-AlInP-GaAs junction at the front of the cell. This series resistance reduces the fill factor, and, therefore, the efficiency of the solar cell.

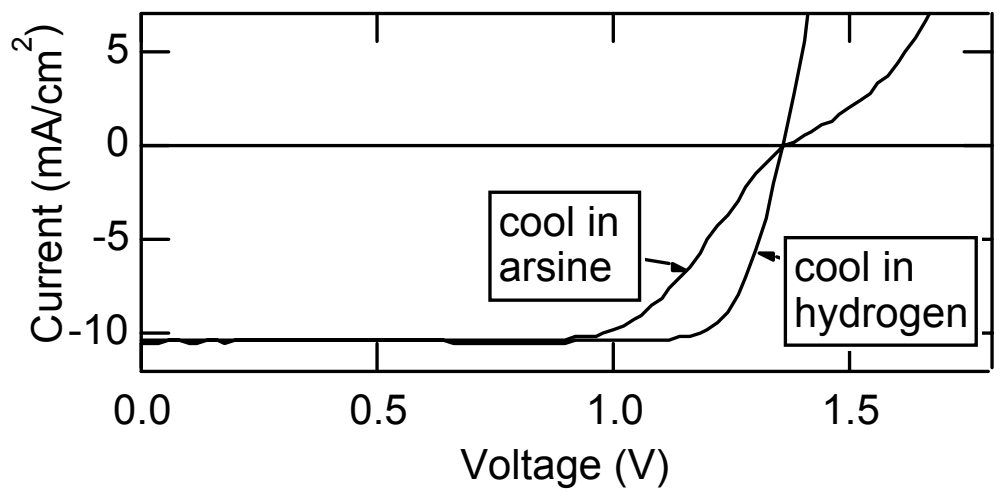

Fig. 11. IV curves for two GaInP cells grown identically, but cooled differently.

\section{SUMMARY}

We calculated the QE for GaInP cells with front and back-surface interface recombination velocities between 1000 and $10^{7} \mathrm{~cm} / \mathrm{s}$. These curves showed that IRVs $<10^{4} \mathrm{~cm} / \mathrm{s}$ are needed for effectively ideal passivation. Poor passivation of the front of the cell reduces the photocurrent (primarily by loss of blue response) as well as the photovoltage. Passivation of the back of a thick cell affects the red response and photovoltage of the cell, but has a negligible effect on a thick p-on-n cell. Thin cells (often needed for multijunction stacks) show an improved photovoltage and photocurrent if well passivated, even for the p-on-n design.

Although very low IRVs are reported in the literature, because of the need to dope the cells and the complexities of cell growth, much higher IRVs are frequently observed in solar cells. Dopant diffusion during growth can help or hinder passivating schemes, while accidental or intentional addition of oxygen and/or hydrogen can reduce passivation and increase barriers to majority-carrier flow. Low photovoltage from high IRV can be differentiated from low photovoltage from high defect densities by looking at the diode ideality factor.

\section{APPENDIX-ABSORPTION COEFFICIENT OF GaInP}

Although ellipsometric studies of the optical properties of GaInP and AlInP $[25,26]$ have been reported in the literature, accurate modeling of GaInP solar cells requires more detailed 
knowledge of the absorption coefficient, $\alpha$. A complication of evaluating $\alpha \bullet$ is that the band gap and optical properties of GaInP vary with growth conditions [13,27]. Also, $\alpha$ varies with doping. A detailed investigation of $\alpha$ as a function of both ordering and doping is lacking, but we find that we can model GaInP cells reasonably well using the approach presented below.

The ellipsometric studies measure the dielectric constants, $\varepsilon 1$ and $\varepsilon 2$, accurately in regions of high absorption, but give fairly inaccurate results near the band edge. Kato, et al. presented data and empirical equations fitting the data [25]. However, their empirical equations are inaccurate near the band edge (see Fig. 12) and include a tail extending well below the band gap. The curves presented in Fig. 13 of reference [25] were modified at the band edge to improve the accuracy, but the modification procedure was not described [28]. We have measured the absorption near the band edge using a simple transmission measurement and find that the nearband-edge data can be fit by

$$
\alpha(E)=5.5 \sqrt{\left(E-E_{g}\right)}+1.5 \sqrt{\left(E-E_{g}-0.1\right)}
$$

where $E$ is the photon energy and $E g$ is the fundamental band gap, both in $\mathrm{eV}$, and $\alpha$ in $1 / \mu \mathrm{m}$.

This equation assumes a parabolic direct gap and is accurate near the band edge, but not at higher energies (see Fig. 12, "Direct gap only" trace). The absorption at the band edge is much weaker than the absorption associated with the $\mathrm{E}_{1}$ transition. Omission of this higher absorption (especially in the AlInP window) prevents useful modeling of GaInP solar cells. Kato's data are accurate for photon energy $>3 \mathrm{eV}$, but not near the band edge. To obtain the fits presented in Fig. 3 , we have used the band-edge data for $\mathrm{E}<2.7 \mathrm{eV}$ and Kato's empirical fit for $\mathrm{E}>3.1$, with a smooth connection between the two (see dotted line in Fig. 12).

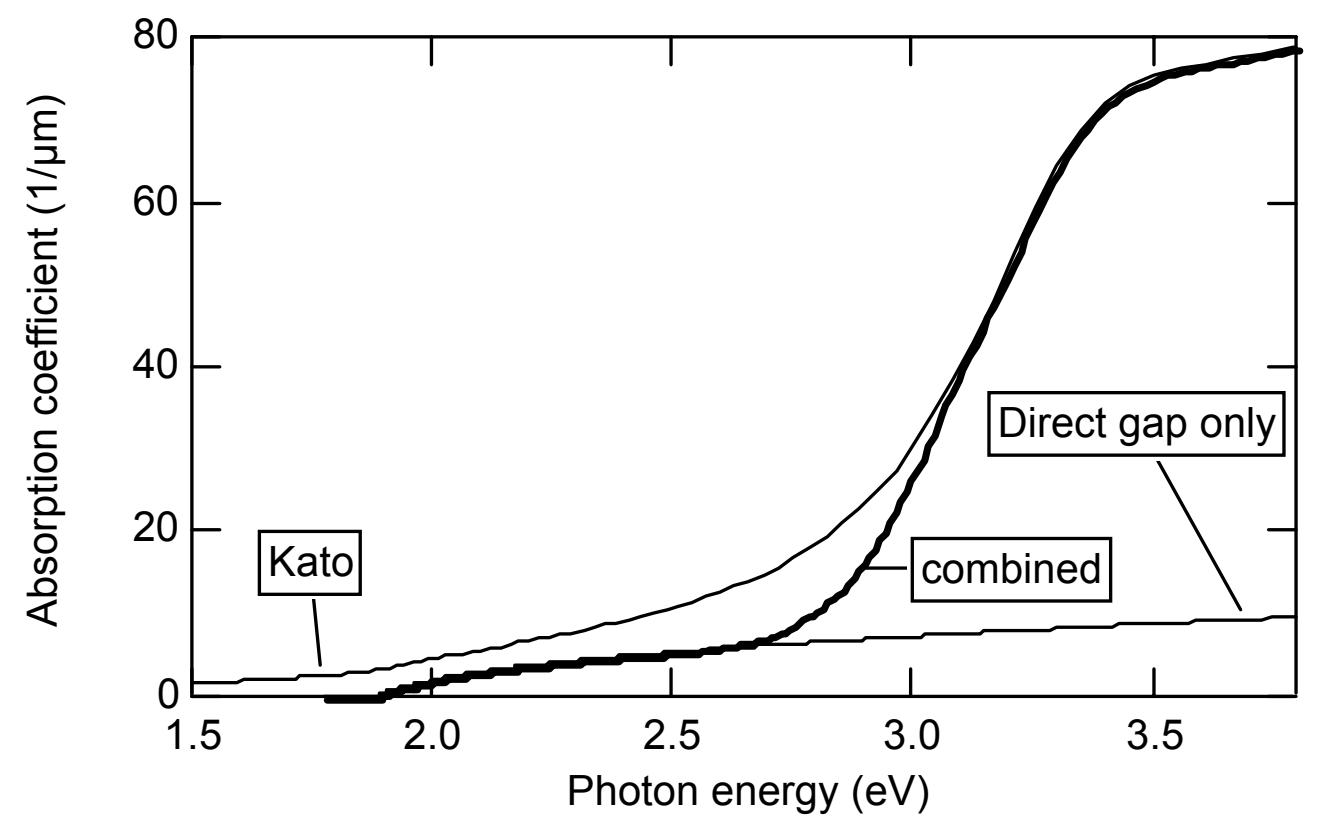

Fig. 12. Compares GaInP absorption coefficient using Kato's published empirical fit [25], direct-gap absorption near the band edge, and a combination of the two. The "combined" curve was used for the calculations presented in this paper. Use of either of the two other curves gave unsatisfactory fits. 


\section{ACKNOWLEDGMENTS}

We would like to thank C. Kramer for preparing the samples, K. Jones for the TEM micrograph, R. Reedy for the SIMS measurements, and R. King for useful conversations. This work was supported under DOE contract DE-AC36-98-G010337.

\section{REFERENCES}

1. K. A. Bertness, S. R. Kurtz, D. J. Friedman, A. E. Kibbler, C. Kramer, and J. M. Olson, Appl. Phys. Lett. 65, 989-991 (1994).

2. D. J. Friedman, S. R. Kurtz, K. A. Bertness, A. E. Kibbler, C. Kramer, J. M. Olson, D. L. King, B. R. Hansen, and J. K. Snyder, Progress in Photovoltaics: Research and Applications 3, 47-50 (1995).

3. T. Takamoto, E. Ikeda, H. Kurita, M. Ohmori, M. Yamaguchi, and M. J. Yang, Jpn. J. Appl. Phys. 36, 6215-6220 (1997).

4. Y. C. M.Yeh, F. F. Ho, C. L. Chu, and P. K. Chiang, "Advance in Production of Cascade Solar Cells for Space," in Proceedings of the 26th IEEE Photovoltaic Specialists Conference, 1997, 827-830.

5. B. T. Cavicchi, J. H. Ermer, D. D. Krut, D. E. Joslin, M. S. Gillanders, and D. K. Zemmrich, "250,000 Watts of $\mathrm{GaInP}_{2} / \mathrm{GaAs} / \mathrm{Ge}$ Dual Junction Production," in Proceedings of the 2nd World Conference on PV Energy Conversion, 1998, 3515-3519.

6. J. M. Olson, R. K. Ahrenkiel, D. J. Dunlavy, B. Keyes, and A. E. Kibbler, Appl. Phys. Lett. 55, 1208 (1989).

7. H. J. Hovel, Solar Cells, (Academic Press, New York, 1975).

8. A. L. Fahrenbruch and R. H. Bube, Fundamentals of Solar Cells Photovoltaic Solar Energy Conversion, (Academic Press, New York, 1983).

9. S. R. Kurtz, P. Faine, and J. M. Olson, J. Appl. Phys. 68, 1890 (1990).

10. S. M. Sze, Physics of Semiconductor Devices, (Wiley, New York, 1969).

11. M. S. Carpenter, M. R. Melloch, M. S. Lundstrom, and S. P. Tobin, Appl. Phys. Lett. 52, 2157-2159 (1988).

12. A. Gomyo, T. Suzuki, K. Kobayashi, S. Kawata, I. Hino, and T. Yuasa, Appl. Phys. Lett. 50, 673 (1987).

13. S. R. Kurtz, J. M. Olson, and A. Kibbler, Appl. Phys. Lett. 57, 1922-1924 (1990).

14. M. E. Klausmeier-Brown, M. S. Lundstrom, M. R. Melloch, and S. P. Tobin, Appl. Phys. Lett. 52, 2255-2257 (1988).

15. K. Meehan, F. P. Dabkowski, P. Gavrilovic, J. E. Williams, W. Stutius, K. C. Shieh, and N. Holonyak, Appl. Phys. Lett. 54, 2136-2138 (1989).

16. L. W. Molenkamp and H. F. J. van't Bilk, J. Appl. Phys. 64, 4253 (1988).

17. R. R. King, J. H. Ermer, D. E. Joslin, M. Haddad, J. W. Eldredge, N. H. Karam, B. Keyes, and R. K. Ahrenkiel, "Double heterostructures for characterization of bulk lifetime and interface recombination velocity in III-V multijunction solar cells," in Proceedings of the 2nd World Conference on Photovoltaic Solar Energy Conversion, 1998, 86.

18. R. K. Ahrenkiel, J. M. Olson, D. J. Dunlavy, B. M. Keyes, and A. E. Kibbler, Journal of Vacuum Science and Technology B 8, 3002 (1990).

19. R. J. Nelson, J. Vac. Sci. Technol. 15, 1475 (1978). 
20. A. van Geelen, in Solar Cells of the III-V Compounds GaAs and GaInP2, PhD thesis (1997).

21. S. R. Kurtz, J. M. Olson, K. A. Bertness, K. Sinha, B. McMahon, and S. Asher, "Hidden but important parameters in GaInP cell growth," in Proceedings of the 25th IEEE Photovoltaic Specialists Conference, 1996, 37-42.

22. D. G. Deppe, Appl. Phys. Lett. 56, 370-372 (1990).

23. S. R. Kurtz, J. M. Olson, D. J. Friedman, and R. Reedy, "Effect of Front-Surface Doping on Back-Surface Passivation in GaInP Cells," in Proceedings of the 26th IEEE Photovoltaic Specialists Conference, 1997, 819-822.

24. D. J. Friedman, S. R. Kurtz, A. E. Kibbler, and J. M. Olson, "Back surface fields for GaInP 2 solar cells," in Proceedings of the 22nd IEEE Photovoltaic Specialists Conference, 1991, 358-360.

25. H. Kato, S. Adachi, H. Nakanishi, and K. Ohtsuka, Jpn. J. Appl. Phys. 33, 186-192 (1994).

26. K. H. Lee, S. G. Lee, and K. J. Chang, Phys. Rev. B. 52, 15862-15866 (1995).

27. S. R. Kurtz, D. J. Arent, K. A. Bertness, and J. M. Olson, "The Effect of Phosphine Pressure on the Band Gap of $\mathrm{Ga}_{0.5} \mathrm{In}_{0.5} \mathrm{P}$," in Proceedings of the Compound Semiconductor Epitaxy, 1994, 117-122.

28. S. Adachi (private communication). 


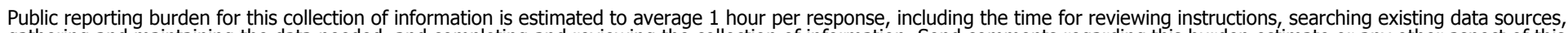

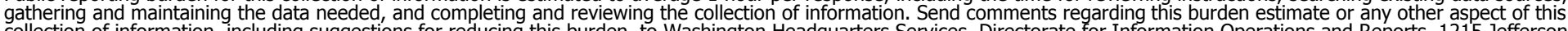

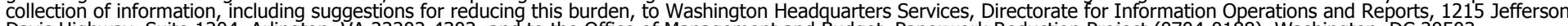

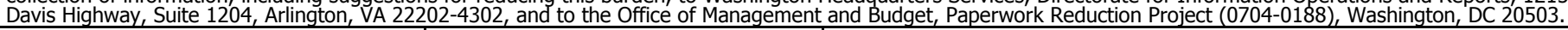

\begin{tabular}{|l|l|l|l|}
\hline 1. AGENCY USE ONLY (Leave blank) & $\begin{array}{l}\text { 2. REPORT DATE } \\
\text { May 1999 }\end{array}$ & $\begin{array}{l}\text { 3. REPORT TYPE AND DATES COVERED } \\
\text { Conference Paper }\end{array}$ \\
\hline 4. TITLE AND SUBTITLE &
\end{tabular}

Passivation of Interfaces in High-Efficiency Photovoltaic Devices

6. AUTHOR(S)

S.R. Kurtz, J.M. Olson, K. Bertness, D.J. Friedman, J.F. Geisz, and A.E. Kibbler

5. FUNDING NUMBERS

$\mathrm{C}$ :

TA: PV904401

7. PERFORMING ORGANIZATION NAME(S) AND ADDRESS(ES)

National Renewable Energy Laboratory

8. PERFORMING ORGANIZATION

1617 Cole Blvd. REPORT NUMBER

Golden, CO 80401-3393

9. SPONSORING/MONITORING AGENCY NAME(S) AND ADDRESS(ES)

10. SPONSORING/MONITORING AGENCY REPORT NUMBER

JA-590-26494

11. SUPPLEMENTARY NOTES

12a. DISTRIBUTION/AVAILABILITY STATEMENT

National Technical Information Service

U.S. Department of Commerce

5285 Port Royal Road

Springfield, VA 22161

13. ABSTRACT (Maximum 200 words)

Solar cells made from III-V materials have achieved efficiencies greater than $30 \%$. Effectively ideal passivation plays an important role in achieving these high efficiencies. Standard modeling techniques are applied to $\mathrm{Ga}_{0.5} \mathrm{In}_{0.5} \mathrm{P}$ solar cells to show the effects of passivation. Accurate knowledge of the absorption coefficient is essential (see appendix). Although ultralow $(<2 \mathrm{~cm} / \mathrm{s})$ interface recombination velocities have been reported, in practice, it is difficult to achieve such low recombination velocities in solar cells because the doping levels are high and because of accidental incorporation of impurities and dopant diffusion. Examples are given of how dopant diffusion can both help and hinder interface passivation, and of how incorporation of oxygen or hydrogen can cause problems.

\section{SUBJECT TERMS}

photovoltaics ; passivation ; high-efficiency devices ; recombination

\begin{tabular}{l|l}
\hline 17. SECURITY CLASSIFICATION & 18. SECURITY CLASSIFICATION \\
OF REPORT & OF THIS PAGE \\
Unclassified & Unclassified
\end{tabular}

NSN 7540-01-280-5500
15. NUMBER OF PAGES

12

19. SECURITY CLASSIFICATION OF ABSTRACT Unclassified
16. PRICE CODE

Standard Form 298 (Rev. 2-89) Prescribed by ANSI Std. Z39-18 